\title{
FISHERIES REGULATIONS BASED ON YIELD PER RECRUIT ANALYSIS FOR THE SPOTTED SEABASS DICENTRARCHUS PUNCTATUS (MORONIDAE) AT BARDAWIL LAGOON, MEDITERRANEAN COAST OF SINAI, EGYPT
}

\author{
Sahar F. Mehanna \\ National Institute of Oceanography and Fisheries \\ sahar_mehanna@yahoo.com
}

Keywords: Bardawil lagoon, Moronidae, Dicentrarchus punctatus, age validation, per-recruit analysis, fisheries regulations.

\section{ABSTRACT}

7 The spotted seabass Dicentrarchus punctatus in Bardawil Lagoon was assessed using Beverton and Holt relative yield per recruit model. A total of 879 specimens were collected during two fishing seasons between April 2004 and December 2005. The maximum life span was four years for length range of $13.8-35 \mathrm{~cm}$ TL. The parameters of the von Bertalanffy growth function were $\mathrm{K}=0.581$ year $^{-1}, \mathrm{~L}_{\infty}=37.476 \mathrm{~cm}$ and $\mathrm{t}_{0}=-0.227$ years. The rates of total mortality $\mathrm{Z}$ and natural mortality $\mathrm{M}$ were 1.32 and 0.40 year $^{-1}$ respectively. Rates of fishing mortality $\mathrm{F}=$ 0.92 year $^{-1}$ and exploitation $\mathrm{E}=0.70$ indicate that the population of this species is being heavily exploited. The estimated total length at first capture $\mathrm{L}_{\mathrm{c}}$ was $14.8 \mathrm{~cm}$, while the total length at $50 \%$ maturity was 25.13 $\mathrm{cm}$. Reproductive activity of spotted seabass took place between November and February, with the greatest intensity in December. Yield per recruit analysis revealed over-fished stock conditions particularly because small fish are effectively unprotected by current minimum size regulations. Based on the analysis it is recommended that the commercial fishery of Bardawil Lagoon should be subjected to a total allowable catch, bag limits should be lowered and a maximum size limit be implemented.

\section{INTRODUCTION}

Seabasses (Dicentrarchus labrax and D. punctatus) are common in the Mediterranean Sea, the Black Sea and along the Eastern Atlantic coasts from Great Britain to Senegal. These species are found in marine to slightly brackish environments such as coastal lagoons and estuarine areas. They are euryhaline and eurythermal species, meaning they have tolerances for wide salinity and temperature fluctuations (Moretti et al., 
1999). Seabasses are predators, consuming small fish and a large variety of invertebrates. The feeding behaviour is related to size; juveniles feed mainly on small crustaceans (Amphipoda, Mysidacea and Isopoda) and small fish like Atherina and Gobius. In fish larger than $20 \mathrm{~cm}$, shrimps and crabs begin to be common preys.

Spotted seabass $D$. punctatus, which locally known as nokt along with European seabass D. labrax (karous) are contributed about $2.4 \%$ of the total landing of the Bardawil Lagoon. In contrast to D. labrax, which heavily studied in the Egyptian water bodies (Rafail, 1971; Blostein, 1976; Pisanty, 1981; Abo-zied, 1987; Wassef and El-Emary, 1989; Abdel-Baky, 1997; Hegazy and Sabry, 2001; Abd-Alla, 2004; Haggag, 2005; Khalifa, 2005), there is no recorded studies on the biology and fisheries of $D$. punctatus. So, the present work is directed to provide a preliminary assessment of $D$. punctatus in Bardawil Lagoon. This may help to suggest the required fisheries regulations to sustain and manage this valuable fish resource.

\section{MATERIAL AND METHODS}

A total of 879 individuals of $D$. punctatus $(13.8-35 \mathrm{~cm}$ TL) were randomly collected from the commercial catch of the Bardawil Lagoon through two fishing seasons, 2004 and 2005 (from April to December). Each fish was measured to the nearest $\mathrm{mm}$ for total length and weighed to the nearest 0.1 gram total weight, then sex and maturity were determined macroscopically. The weight of gonads was recorded to the nearest $0.01 \mathrm{~g}$. Otoliths and scales were taken for each specimen, cleaned and stored dry for later age determination. Annual rings on otoliths were identified and counted using optical system consisting of Nikon Zoom - Stereomicroscope and Heidenhain's electronic bidirectional read out system V R X 182, under transmitted light. Scales were washed with distilled water and mounted dry between two glass slides then examined using measuring projector "LEITZ TP 300" connected to an electronic reversible counter LEITZ VRZ U. The total radius of each otolith and scale and the radius of each annulus were measured to the nearest $0.001 \mathrm{~mm}$. Regression analyses of otolith and scales maximum radius on total length was calculated by the method of least squares. Back-calculated lengths-at-age were computed by using the Lee method (Lagler, 1956).

Counts of the growth bands were done for both otoliths and scales and the precision was measured by the percentage of agreement between the two readings (Lowerre-Barbieri et al., 1994). Only counts with 
agreements were used in subsequent analysis. Reproducibility of the resultant age estimation was evaluated with the coefficient of variation (CV) (Chang, 1982) and the index of average percent error (IAPE) (Beamish and Fournier, 1981).

To estimate the relation between total length $(\mathrm{L})$ and total weight (W), the variables were log-transformed to meet the assumptions of normality and homogeneous variance. A linear version of the power function: $\mathrm{W}=\mathrm{a} \mathrm{L}^{\mathrm{b}}$ was fitted to the data. Confidence intervals (CI) were calculated for the slope to see if it was statistically different from 3.

Growth curves, based on biological ages were constructed using the von Bertalanffy growth function as: $\mathrm{L}_{\mathrm{t}}=\mathrm{L}_{\infty}\left(1-\mathrm{e}^{-\mathrm{k}(\mathrm{t}-\mathrm{to})}\right)$ where $\mathrm{L}_{\mathrm{t}}=$ length at time $\mathrm{t}, \mathrm{L}_{\infty}=$ asymptotic length, $\mathrm{k}=$ growth coefficient, $\mathrm{t}=$ time, and $\mathrm{t}_{0}=$ age at time zero.

The total mortality coefficient $\mathrm{Z}$ was estimated using the semilogarithmic method as described in Ricker (1975). The natural mortality coefficient $\mathrm{M}$ was estimated as the geometric mean of two methods (Taylor, 1960; Ursin, 1967), while the fishing mortality coefficient $\mathrm{F}=$ $\mathrm{Z}-\mathrm{M}$ and the exploitation rate $\mathrm{E}$ was estimated as $\mathrm{E}=\mathrm{F} / \mathrm{Z}$ (Gulland, 1971).

The length at first sexual maturity $\mathrm{L}_{50}$ (the length at which $50 \%$ of fish reach their sexual maturity) was estimated by fitting the maturation curve between the observed points of mid-class interval and the percentage maturity of fish corresponding to each length interval. Then $\mathrm{L}_{50}$ was estimated as the point on $\mathrm{X}$-axis corresponding to $50 \%$ point on $\mathrm{Y}$-axis, while the length at first capture $\mathrm{L}_{\mathrm{c}}$ was estimated by the analysis of catch curve, using the method of Pauly (1984). The spawning season was detected by following the monthly variation in both gonado-somatic index and maturity stages.

The relative yield per recruit (Y/R)' and relative biomass per recruit $(\mathrm{B} / \mathrm{R})$ ' were estimated by using the model of Beverton and Holt (1966) as modified by Pauly and Soriano (1986).

\section{Description of the fishery}

\section{RESULTS AND DISCUSSION}

Bardawil Lagoon is a shallow (0.3 to $3 \mathrm{~m}$ depth) and hyper-saline lagoon on the northern coast of Sinai. It lies between Lat $33^{\circ} 0^{\prime}$ East $31^{\circ}$ 9' North and covers an area of about $650 \mathrm{~km}^{2}$, with about $85 \mathrm{~km}$ length and a maximum width of $22 \mathrm{~km}$. It is separated from the sea by a sandbar that varies in width between $100 \mathrm{~m}$ and $1 \mathrm{~km}$. Three openings connect the Lagoon with the sea; two artificial openings at the West side 
(Boughaz I and Boughaz II) and one natural opening at the East (ElZaranik). Bardawil Lagoon, particularly at Zaranik, has been identified as one of the most important wetlands for water-birds in the whole Mediterranean region (Fig. 1). Bardawil Lagoon is a source of an important local fishery, producing over 2,300 ton annually (GAFRD) and employing some 3,000 fishermen. Fishing is prohibited between January and April. A number of fishing methods are used in the lagoon including Dabba or trammel nets, El-Bouss or veranda, Kalsa or trawl nets, Lines or sinnar, El-Dahbana nets and El-Tair nets.

\section{Catch statistics}

Seabasses are one of the important fishes in Bardawil Lagoon. In late 1980's and early 1990's, seabasses were exported to Europe, where their catch during this period constituted about $16 \%$ of the total lagoon production. From 1995 inward, catch rates of seabasses in Bardawil Lagoon were decreasing rapidly recording only 35 ton during 2005 (Fig. 2 ). This serious decline in seabass production was due to the irrational management strategy and uncontrolled fish exporting policy in the lagoon. Seabasses are exploited by two fishing methods in the lagoon; trammel nets and lines. The length frequency of seabass caught by trammel nets was smaller than that by lines, where the length of seabasses fished by trammel nets ranged between 13 and $26 \mathrm{~cm}$ TL for D. punctatus and between 16 and $30 \mathrm{~cm}$ TL for D. labrax and that fished by hook and lines ranged between 24 and $35 \mathrm{~cm}$ for $D$. punctatus and between 26 and $71 \mathrm{~cm}$ TL for D. labrax. It is worth mentioning that the fishes of lengths greater than $34 \mathrm{~cm}$ for $D$. punctatus and $60 \mathrm{~cm}$ for $D$. labrax were rarely reported in the catch.

\section{Age validation}

One of the most serious mistakes made by fisheries biologists is the failure to validate the age determination procedure that provides accurate age confirmation of the ageing technique. Without exception, age determination techniques must be validated for all age classes in the population and each time they are applied to a new species. To validate age determination of $D$. punctatus at Bardawil Lagoon, ages were determined by comparing the growth increment readings on sagittal otoliths and scales. It was found that the number of annuli counted for each individual was similar for the two readings and there was a high congruence (96.8\%) between the age estimations from the two hard structures. Of the 879 otoliths and scales examined, consensus reached 812 (92.4\%). The index of average percent error (IAPE) of band counts for each reading did not differ greatly. Precision of repeated age 
estimation was high, scales' readings were $89 \%$ in agreement with otoliths' readings. The values of the IAPE and the CV suggested that the precision levels obtained are according to the reference point values indicated by Campana (2001).

The results revealed that the maximum observed ages for $D$. punctatus at Bardawil Lagoon was four years and age group one was the most frequent group in the catch and constituted 60\%, while the age group four was the least age group and formed $1.14 \%$ of the catch.

\section{Back-calculations and growth in length}

Mean lengths at age were back-calculated for $D$. punctatus as 20.11, 27.35, 31.67 and $34.05 \mathrm{~cm}$ at the $1^{\text {st }}, 2^{\text {nd }}, 3^{\text {rd }}$ and $4^{\text {th }}$ year of life respectively. Observed (empirical) lengths were consistently higher than the back-calculated lengths for individual - age groups, which indicated that seasonal growth had occurred since formation of a new annulus. Differences between back-calculated lengths-at-age and observed lengths are in the range of observed seasonal growth (Table 1). Greatest incremental growth in TL occurred during the first year and then declined rapidly thereafter (Fig. 2).

\section{Length - weight relationship}

Analysis of residual sums of squares indicated no significant difference between the sex-specific length-weight relationships of $D$. punctatus in Bardawil fishery, consequently a power regression was applied to the length-weight data of all individuals combined (Fig. 3). The total length varied from 13.8 to $35 \mathrm{~cm}$, while the total weight ranged between 26 and $385 \mathrm{~g}$ and the resultant equation was: $\mathrm{W}=0.0111$ $\mathrm{L}^{2.9448}\left(\mathrm{r}^{2}=0.9878\right)$

Isometric growth was observed for spotted seabass, as the value of (b) was not deviated significantly from the value 3 (95\%Confidence Interval $=2.9780-2.9115$ ).

The calculated weights by age groups were 76.49, 189.18, 291.36 and $360.66 \mathrm{~g}$ for the $1^{\text {st }}, 2^{\text {nd }}, 3^{\text {rd }}$ and $4^{\text {th }}$ year of life respectively. The growth rate in weight was much slower during the first year of life increasing to reach its maximum at the end of the second year of life, then decreasing with further increasing in age (Fig. 4).

\section{Growth parameters}

A likelihood ratio test (LRT) showed no significant difference between male and female VBGFs growth curves. Back-calculated lengths of pooled data were applied according to Ford (1933). Walford (1946) plot to estimate the von Bertalanffy growth parameters $\left(\mathrm{L}_{\infty}\right.$ and $\left.\mathrm{K}\right)$. The obtained equations were as follows: 
For growth in length

For growth in weight $\quad \mathrm{W}_{\mathrm{t}}=478.30\left(1-\mathrm{e}^{-0.58(\mathrm{t}+0.23)}\right)^{2.9448}$

\section{Mortality and Exploitation Rates}

The total mortality coefficient $\mathrm{Z}$ was estimated as 1.32 year $^{-1}$ (Fig. 5). The natural mortality coefficient $M$ was 0.40 year $^{-1}$, while the fishing mortality coefficient $\mathrm{F}$ was 0.92 year $^{-1}$. Exploitation rate $\mathrm{E}$ was computed as 0.70. Gulland (1971) suggested that the optimum exploitation rate for any exploited fish stock is about 0.5 , at $\mathrm{F}_{\mathrm{opt}}=\mathrm{M}$. More recent, Pauly (1987) proposed a lower optimum $\mathrm{F}$ that equals to 0.4 $\mathrm{M}$. In the present study, $\mathrm{F}$ was higher than the two values of $\mathrm{F}_{\text {opt }}$ given by Gulland (1971) and Pauly (1987) indicating that the stock of $D$. punctatus in Bardawil Lagoon is heavily exploited.

\section{Length and age at first capture}

The length at first capture at which $50 \%$ of the fish are vulnerable to capture was estimated as $14.8 \mathrm{~cm}$, which corresponding to an age of 0.65 year (Fig. 6).

\section{Spawning season and length at first sexual maturity}

There is only one breeding season per year for D. punctatus, which takes place in winter (November to early March), where the highest values of G.S.I. and the highest percentages of ripe gonads were recorded. Sexual maturity takes place earlier in males than females (at age of $1.46^{+}$years and length range of $17-24 \mathrm{~cm}$ for males and at age of $1.75^{+}$years and length range of $20-27 \mathrm{~cm}$ for females). Spawning of spotted seabass takes place in offshore Mediterranean water. Spotted seabass, D. punctatus attained its first sexual maturity at $25.13 \mathrm{~cm}$ in Bardawil Lagoon which corresponding to an age of 1.69 years. It was noticed that the majority of spotted seabass caught in Bardawil Lagoon were immature which represented by about $51 \%$ of total seabass' catch. Therefore, in order to protect this species and to enable it to share at least for one time in reproduction, the mesh sizes must be re-evaluated. Based on the percentage of immature fishes to total catch, the fishing gears used for this species could be considered very harmful, where Cetini et al. (2002) stated that, if the ratio of immature specimens in the total catch is above $50 \%$, fishing gear would be considered very harmful and if it is between 20 and $50 \%$, it is medium harmful, but if it is under $20 \%$, then the harmful influence of fishing gear is acceptable. 


\section{Per - recruit analysis and reference points}

The plot of relative yield per recruit $Y^{\prime} / R$ and relative biomassper-recruit $\left(\mathrm{B}^{\prime} / \mathrm{R}\right)$ of $D$. punctatus from Bardawil fishery against exploitation rate $E$ gives a maximum $\left(Y^{\prime} / R\right)$ at $E=0.58$. Also the exploitation level which maintains the spawning stock biomass at $50 \%$ of the virgin spawning biomass $E_{0.5}$ was estimated as 0.35 . This indicates that the current $\mathrm{E}$ and $\mathrm{F}$ were higher than those which gives the maximum $\mathrm{Y}^{\prime} / \mathrm{R}$ and maintains $50 \%$ of the unexploited stock biomass $\left(E_{0.5}\right)$. At the present level of exploitation, and when we raised the length at first capture to $18.75 \mathrm{~cm}\left(\mathrm{~L}_{c} / \mathrm{L}_{\infty}=0.5\right)$, the yield per recruit increased by about $19 \%$ and when it raised to the length at first sexual maturity, the yield per recruit increased by about 53\% (Fig. 7). The same trend was noticed for biomass per recruit, when we raised the length at first capture to $18.75 \mathrm{~cm}$, the biomass per recruit increased by about $20.2 \%$ and when it was raised to the length at first sexual maturity, the Biomass per recruit increased by about $66.7 \%$ (Fig. 8).

It can be concluded that the $D$. punctatus stock in the Bardawil fishery is in a situation of overexploitation, and to sustain this valuable fishery resource some management regulations, including reduction of the present level of exploitation and increasing the length at first capture should be applied. This could be achieved through regulation of mesh sizes, proposing the total allowable catch from the lagoon and protecting the spawning stocks during their spawning migrations from and to the lagoon. Moreover, the destructive fishing gears such as kalsa and dahbana nets should be banned, meanwhile the technological improvement and biological influence of various fishing methods operating inside the lagoon should be taken into account when we analyse the impact of the fishery on the different fish stocks.

\section{REFERENCES}

Abd-Alla, S. M. (2004). Biological studies for the fishery regulations and management of the Bardawil lagoon. Ph. D. Thesis, Fac. Env. Agri. Sci., Suez Canal Univ., 184 pp.

Abdel-Baky, T. E. (1997). Length - weight relationship, relative condition factor, gonad index and maturation of seabass, 
Dicentrarchus labrax L. in Lake Manzalah, Egypt. J. Egypt. Ger. Soc. Zool., 24 (B): 47-66.

Abo-Zied, M. M. (1987). Biological studies on the fish Dicentrachus labrax (L.) in Suez canal region. M.Sc. Thesis. Fac. Sci. Suez Canal Univ. 142pp.

Beamish, R. J. and Fournier, D. A. (1981). A method for comparing the precision of a set of age determinations. Can. J. Fish. Aquat. Sci., 38: 982-983.

Bertalanffy, L. von (1938). A quantitative theory of organic growth (Inquiries on growth Laws. 2). Hum. Biol., 10: 181-213.

Beverton, R. J. H. and Holt, S. J. (1966). Manual of methods for fish stock assessment. Tables of yield functions. FAO Fish. Tech. Pap./ FAO Doc. (38) Rev., 1: 67.

Blostein, I. (1976). The biology of Dicentrarchus labrax in the Bardawil Lagoon. M.Sc. Thesis, Hebrew University of Jerusalem, 42 pp. (in Hebrew)

Campana, S. E. (2001). Accuracy, precision and quality control in age determination, including a review of the use and abuse of age validation methods. J. Fish. Biol. 59:197-242.

Cetini, P.; Soldo, A.; Dul, J. and Pallaoro, A. (2002). Specific method of fishing for Sparidae species in the eastern Adriatic. Fish. Res., 55 (1-3): 131-139.

Chang, W. B. (1982). A statistical method for evaluating the reproducibility of age determinations. Can. J. Fish. Aquat. Sci., 39: $1208-1210$.

Ford, E. (1933). An account of the herring investigations conducted at Plymouth during the years from 1924 to 1933. J. Mar. Biol. Assoc. U. K., 19: 305-384.

Gulland, J. A. (1971). The fish resources of the Ocean. West Byfleet, Surrey, Fishing News (Books), Ltd., for FAO: 255pp. 
Haggag, H. M. (2005). Studies on fishing methods used in Port Said Fishery. Ph. D. Thesis, Faculty of Agriculture, Suez Canal University, 235pp.

Hegazy, M. R and Sabry, E. A. (2001). Stock assessment for the seabass (Dicentrarchus labrax, Linnaeus 1758) - piscs: Moronidae in Bardawil lagoon, Egypt. J. Egypt. Ger. Soc. Zool., 34 (B): 41-55.

Khalifa, U. S. (2005). Population characteristics and fisheries management of European seabass Dicentrarchus labrax L., in Bardawil lagoon, Egypt. Afr. J. Biol. Sci., 1 (1): 69-78.

Lagler, K. E. (1956). Fresh water fishery biology. W. G. Brown co., Dubuque, Lowa. 421pp.

Lowerre-Barbieri, S. K.; Chittenden Jr, M. E. and Jones, C. M. (1994). A comparison of a validated otolith method to age weakfish, Cynoscion regalis, with the traditional scale method. Fish. Bull., 92: 555-568.

Moretti, A.; Pedini Fernandez-Criado, M.; Cittolin, G. and Guidastri, R. (1999). Manual on hatchery production of seabass and gilthead seabream. Vol. 1. Rome, FAO. 194pp.

Pauly, D. (1984a). Length-converted catch curves. A powerful tool for fisheries research in the tropics. (part II). ICLARM Fishbyte, 2 (1): 17-19.

Pauly, D. (1984b). Length-converted catch curves. A powerful tool for fisheries research in the tropics. (III: conclusion). ICLARM Fishbyte, 2 (3): 9-10.

Pauly, D. (1987). A review of the ELEFAN system for analysis of length- frequency data in fish and aquatic invertebrates. ICLARM Conf. Proc., 13: 7-34.

Pauly, D. and Soriano, M. L. (1986). Some practical extensions to Beverton and Holt's relative yield-per-recruit model. In: J. L. Maclean, L. B. Dizon and L. V. Hosillo (eds). The First Asian Fisheries Forum. 491-6. 
Pisanty, S. (1981). the fishery and management of the hypersaline lagoon of Bardawil GFCM stud. Rev. / Etud. Rev.CGPM, 58: 35-73.

Rafail, S. Z. (1971). Investigation on Sciaenidae and Moronidae catch and on the total catch by beach seine on U.A.R. Mediterranean Coast.. Coun. Gen. Peches Médit. Stud. Rev., 48: 1-26.

Ricker, W. E. (1975). Computation and interpretation of biological statistics of fish populations. Bull. Fish. Res. Board Can., 191: 1382.

Taylor, C. C. (1960). Temperature, growth and mortality - the Pacific cockle. J. Cons. CIEM, 26: 117-124.

Ursin, E. (1967). A mathematical model of some aspects of fish growth, respiration and mortality. J. Fish. Res. Bd. Can., 24: 2355-2453.

Walford, L. A. (1946). A new graphic method of describing the growth of animals. Biol. Bull. Mar. Biol. Lab., Woods Hole, 90 (2): 141147.

Wassef, E. A. and El-Emary, H. E. (1989). Contribution to the biology of seabass Dicentrarchus labrax L., in the Egyptian Mediterranean waters of Alexandria. CYBIUM, 13 (4): 327-345. 
Table (1). Back-calculated lengths (cm) and weights (g) at the end of each year of life for Dicentrarchus punctatus from Bardawil lagoon.

\begin{tabular}{|c|c|c|c|c|c|c|c|c|c|c|}
\hline \multirow{2}{*}{ Age(yr) } & \multirow{2}{*}{ No. of fish } & \multirow{2}{*}{$\begin{array}{c}\text { Empirical } \\
\text { length }\end{array}$} & \multicolumn{4}{|c|}{ Back-calculated lengths (cm) } & \multicolumn{4}{|c|}{ Calculated weights (g) } \\
\hline & & & 1 & 2 & 3 & 4 & 1 & 2 & 3 & 4 \\
\hline I & 514 & 21.75 & 20.11 & & & & 76.49 & & & \\
\hline II & 269 & 28.83 & 20.01 & 27.35 & & & 75.38 & 189.18 & & \\
\hline III & 83 & 32.29 & 19.88 & 27.22 & 31.67 & & 73.94 & 186.54 & 291.36 & \\
\hline IV & 13 & 34.45 & 19.83 & 27.09 & 31.55 & 34.05 & 73.40 & 183.93 & 288.12 & 360.66 \\
\hline \multicolumn{3}{|c|}{ Increment } & 20.11 & 7.24 & 4.32 & 2.38 & 76.49 & 112.69 & 102.18 & 69.30 \\
\hline \multicolumn{3}{|c|}{$\%$} & 66.53 & 22.18 & & 11.29 & 21.21 & 31.24 & 28.33 & 19.22 \\
\hline
\end{tabular}




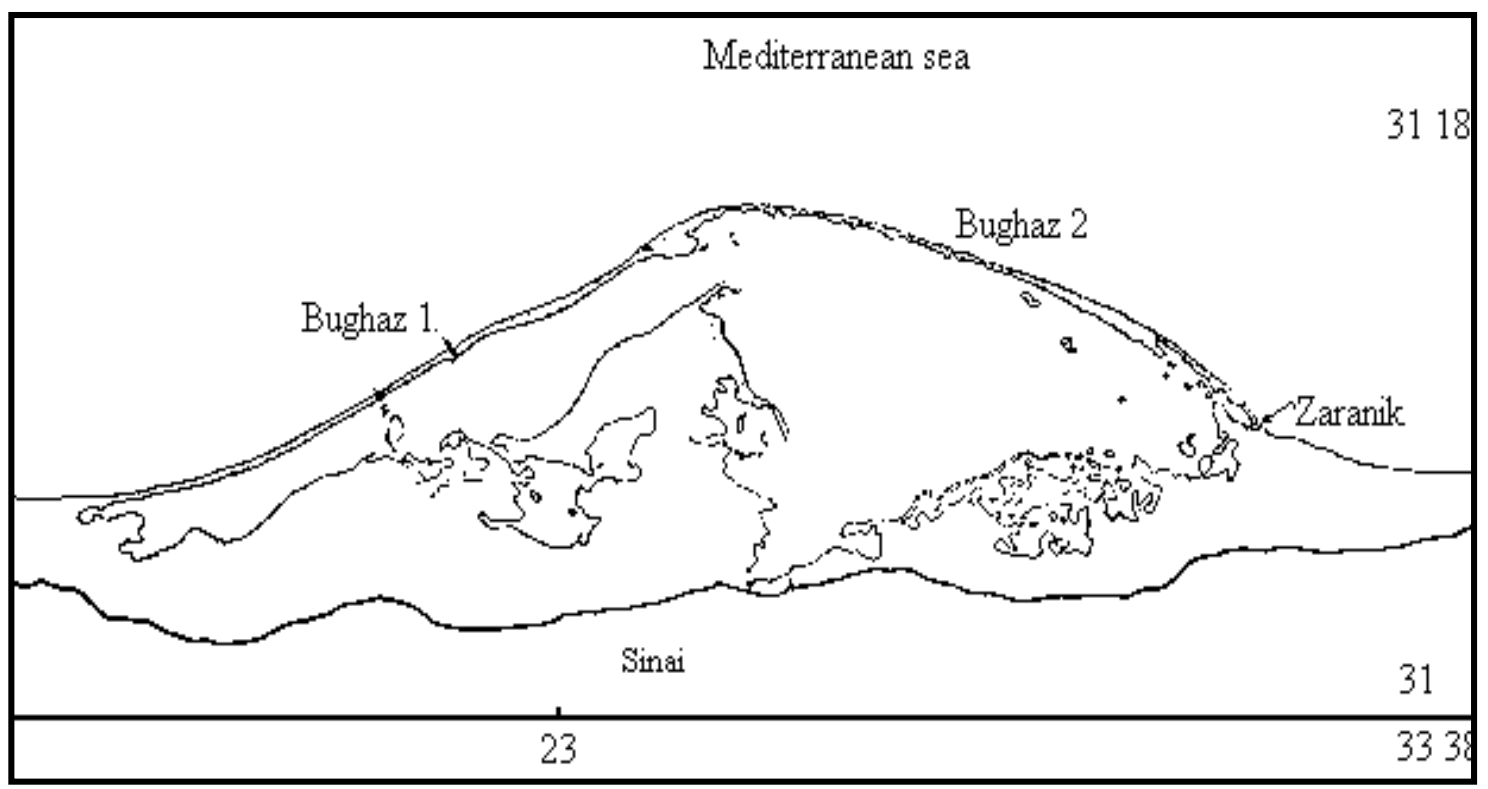

Fig. (1). Bardawil lagoon 


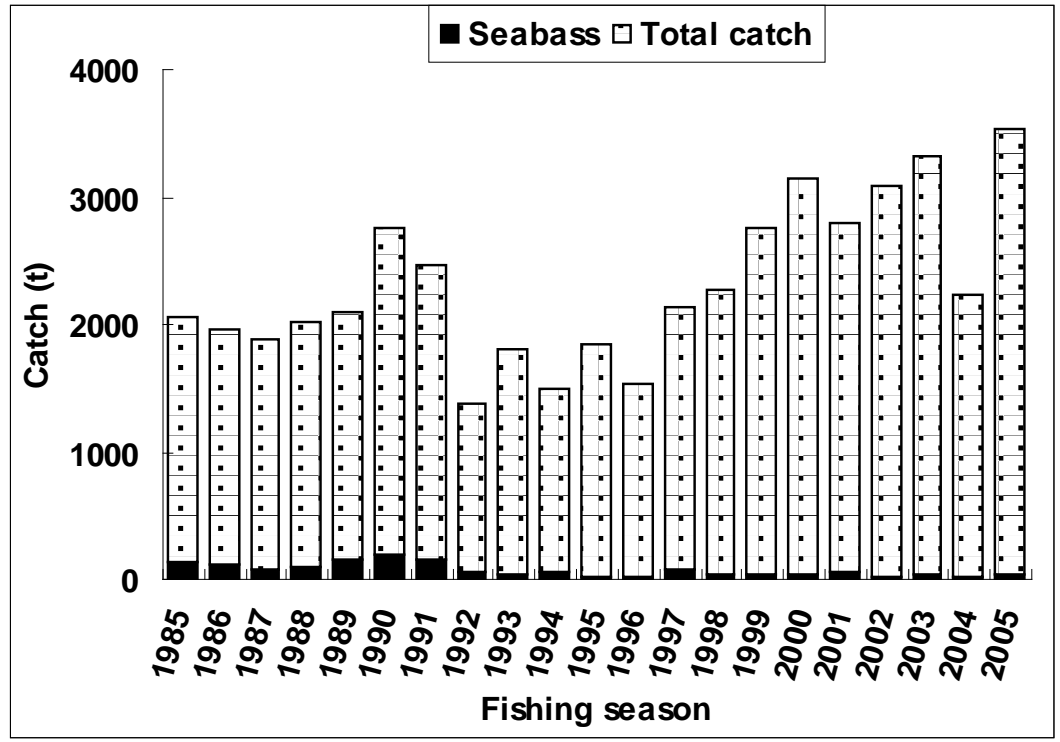

Fig. (2). Total and seabass production from Bardawil lagoon during 1985-2005)

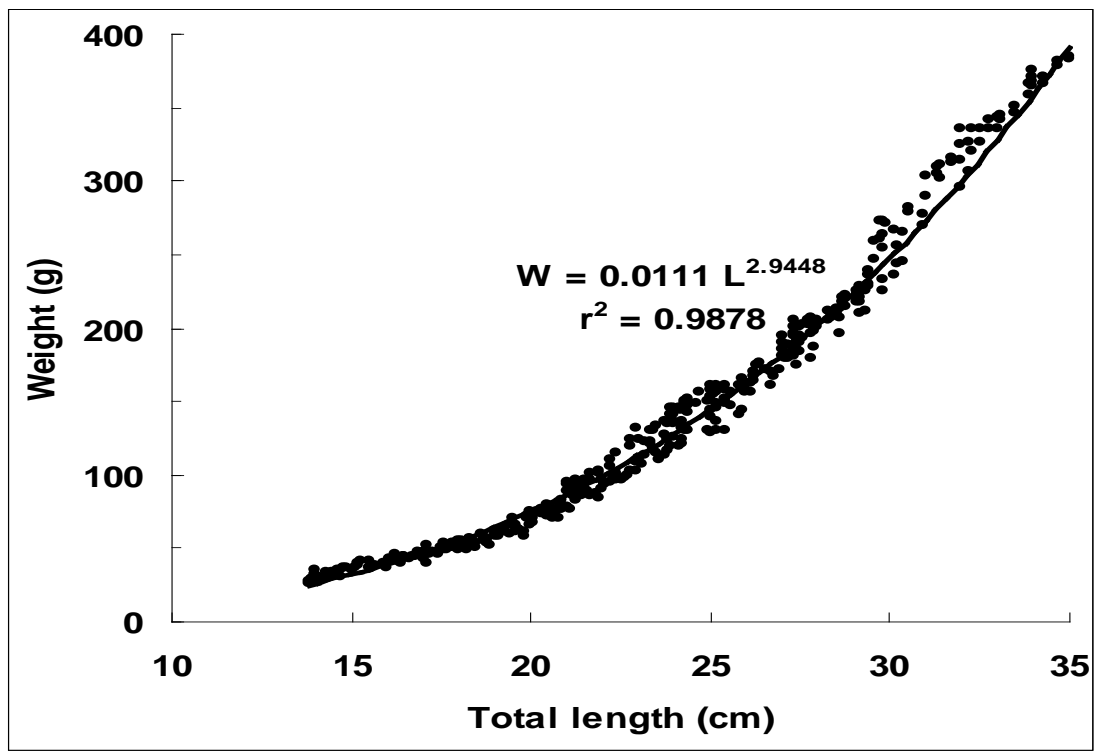

Fig. (3). Length-weight relationship of Dicentrarchus punctatus in Bardawil fishery. 


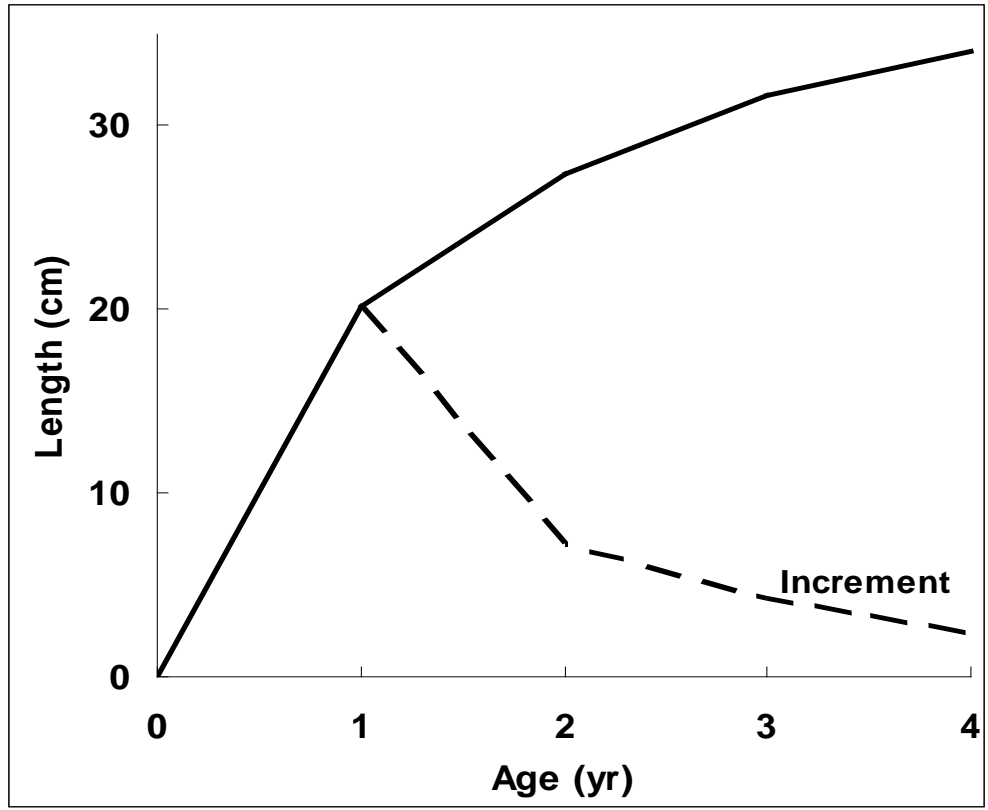

Fig. (4). Growth in length and growth increment of Dicentrarchus punctatus in Bardawil fishery.

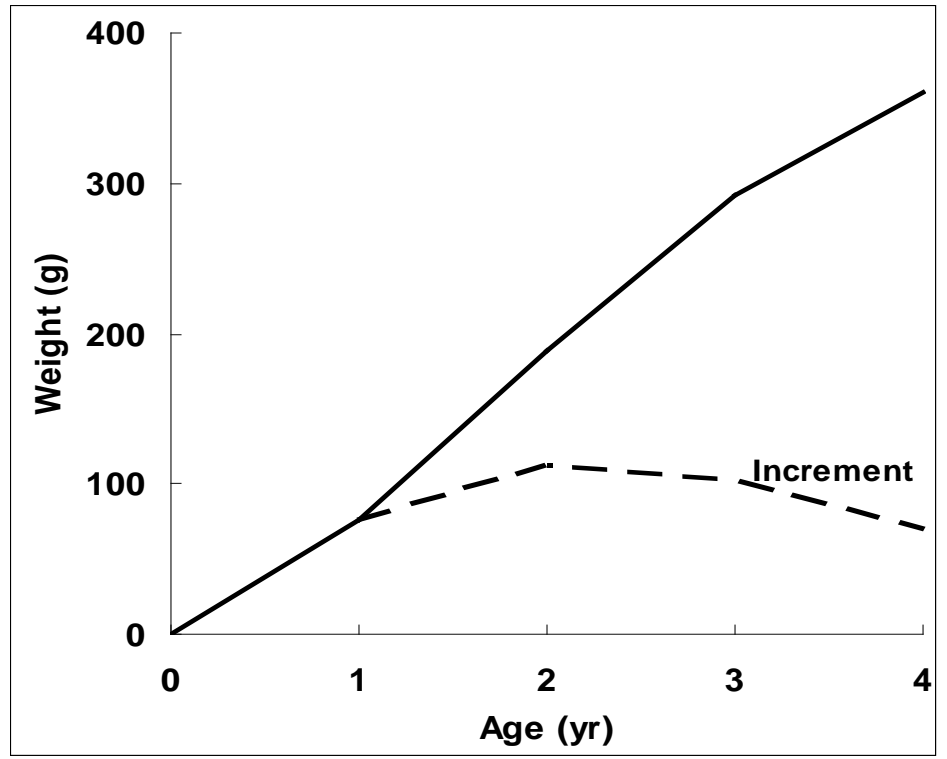

Fig. (5). Growth in weight and growth increment of Dicentrarchus punctatus in Bardawil fishery 
FISHERIES REGULATIONS ON YIELD PER RECRUIT 143 ANALYSIS FOR THE D. PUNCTATUS AT BARDAWIL LAGOON

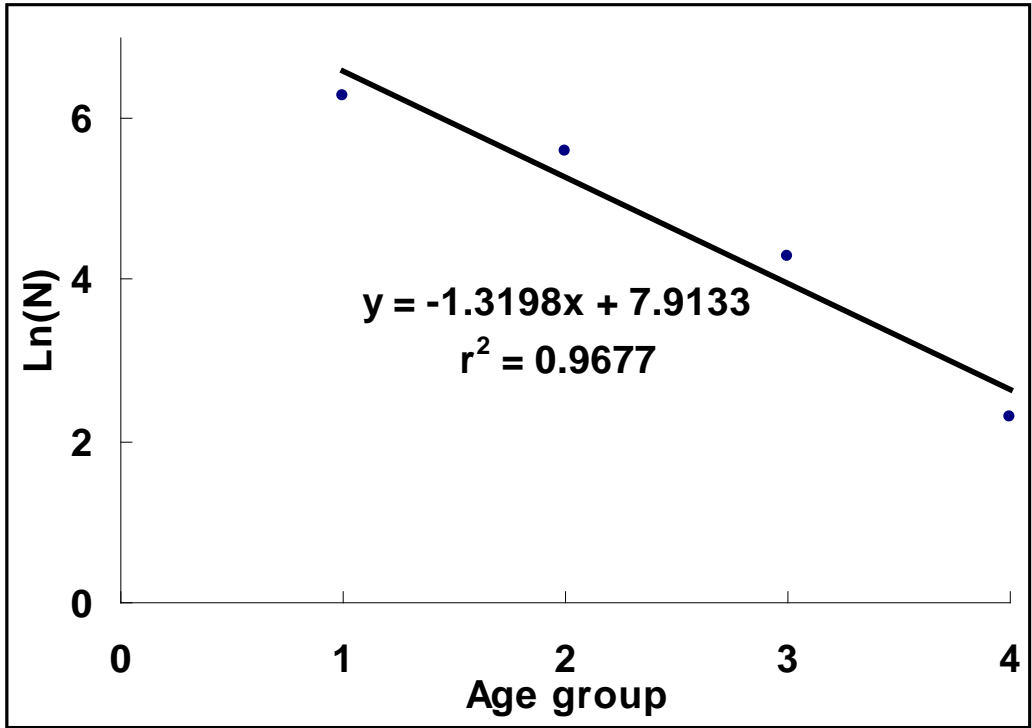

Fig. (6). Z-estimation for Dicentrarchus punctatus from Bardawil fishery.

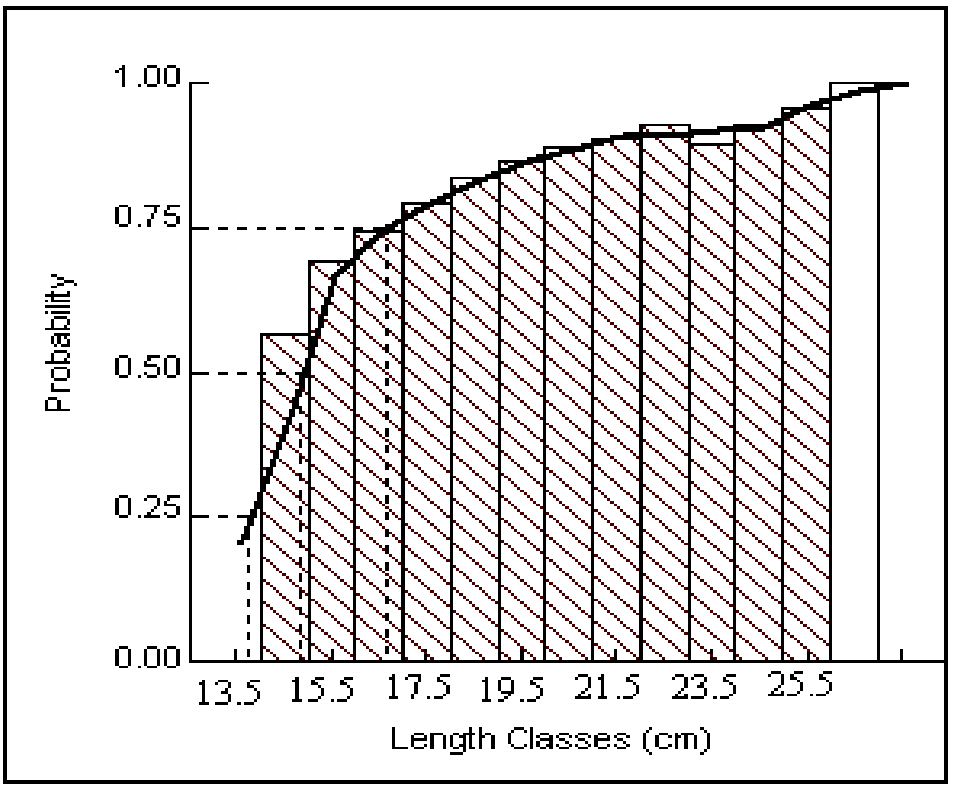

Fig. (7). Probability curve for Dicentrarchus punctatus from Bardawil fishery. 


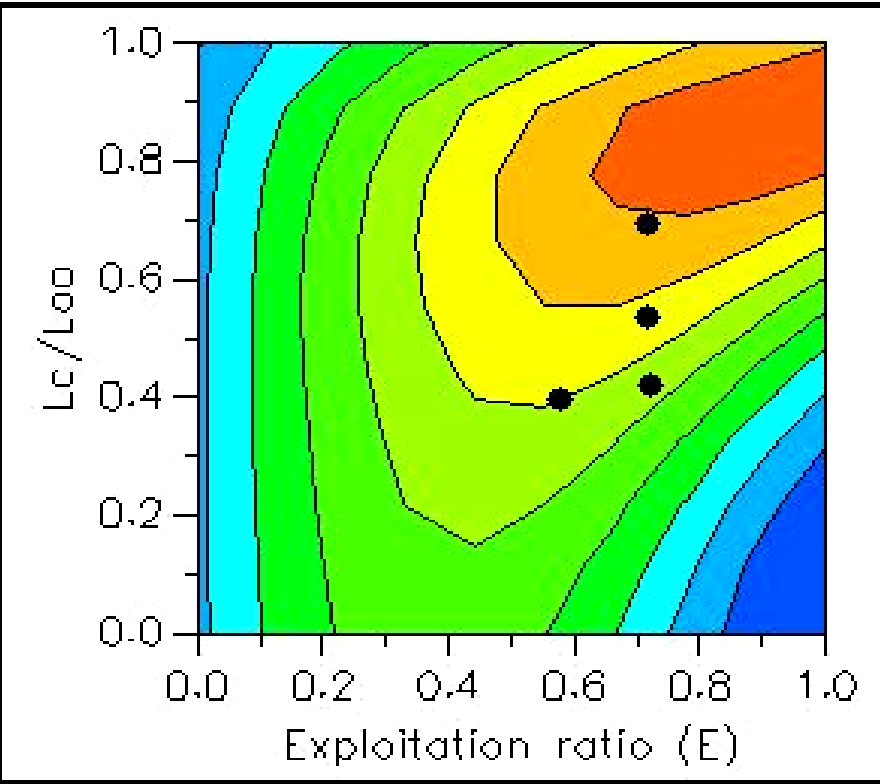

Fig. (8). Yield per recruit analysis for Dicentrarchus punctatus from Bardawil fishery.

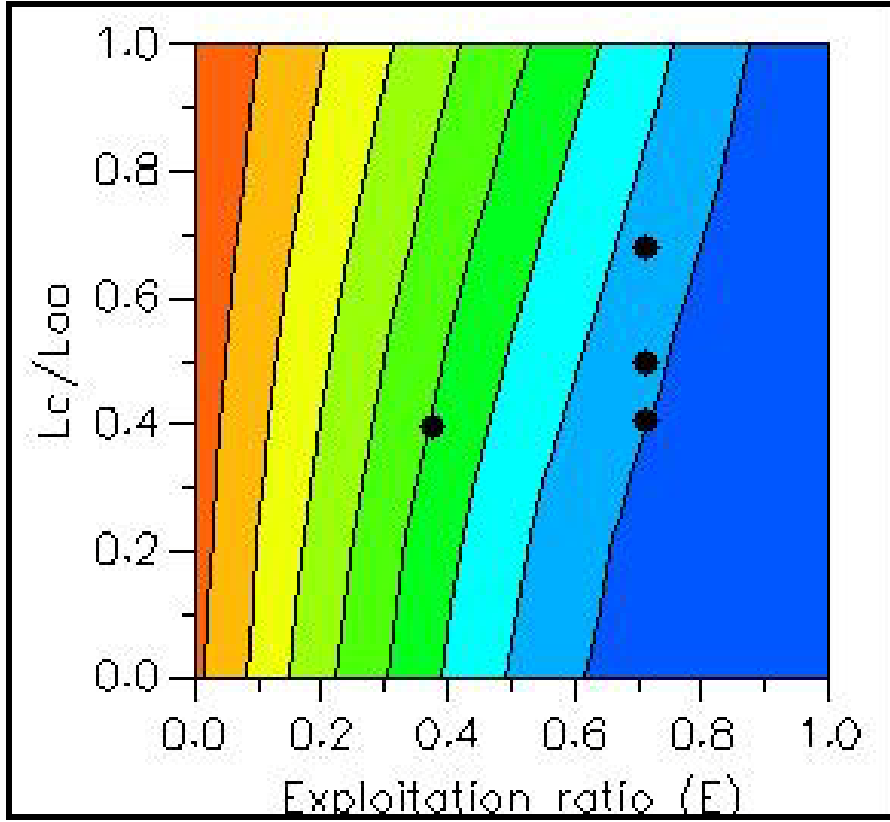

Fig. (9). Biomass per recruit analysis for Dicentrarchus punctatus from Bardawil fishery. 